\title{
MODERNIZATION OF THE REGIONAL ECONOMIC COMPLEX AS THE STRATEGIC FACTOR OF IMPORT SUBSTITUTION NATIONAL POLICY IMPLEMENTATION
}

\author{
Valeriy S. Misakov ${ }^{4}$ Magomed U. Tumgoev 5 , Liza A. Tsuruva ${ }^{6}$, Louisa \\ A. Yandarbayeva ${ }^{7}$, Anzor V. Misakov ${ }^{8}$
}

\begin{abstract}
The article considers the problems of the regional agro-industrial complex modernization as the strategic factor in the implementation of import substitution national policy as one of the priority trends for the restoration and sustainable development of regional economic complexes in the depressed republics of the North Caucasus. And this is not an accident, because one of the most effective methods of national agriculture competitive advantage development can be the project upgrade of the regional agro-industrial complex. We believe that this will provide an opportunity to increase the volume of food products for the country population, to load the processing enterprises of AIF with agricultural raw materials and to provide the food independence for the country.
\end{abstract}

KEY WORDS: crisis, sanctions, strategic management, agro-industrial complex, agribusiness structures of various profiles

JEL: H50

UDC: 005.412:332.142.2(470.62/.67)

005.21:338.43

COBISS.SR-ID 272170764

\footnotetext{
${ }^{4}$ Tembotov Institute of Ecology of Mountain Territories of Russian Academy of Sciences

${ }^{5}$ Department at FSBEI HE "Ingush State University"

${ }^{6}$ Head of "Finance and Credit" Department, FSBEI HE "Ingush State University"

${ }^{7}$ Department of Management and State Municipal Management at FSBEI HE "Chechen State University"

${ }^{8}$ Department at the Institute of Informatics and Regional Administration Problems, FSBSC

FSC "Kabardino-Balkarian Scientific Center of the Russian Academy of Sciences"
} 


\section{INTRODUCTION}

The problems of RF food safety development, the provision of competitive agroindustrial complex, the production of high-quality affordable agricultural products, etc. requires immediate modernization reforms, based on the introduction of innovations in production and economic, economic- organizational and managerial processes. During the development of priority directions for agro-industrial complex development, many questions arise inevitably, including the following: modernization or innovation - what is better? In our case, such a question requires us to consider whether these concepts are identical and, if both are necessary, what aspects of modernization development are needed for the domestic agro-industrial complex.

\section{RESEARCH METHODOLOGY}

The subject of the research are the problems of sustainable and balanced development provision among regional AIC on the basis of their modernization, the creation of innovative-oriented integrated projects as the strategic factors for the implementation of import substitution as a national policy.

Various methods of economic research have been applied: comparative and logical analysis, functional and systemic approach and correlation-regression analysis.

\section{STUDY RESULTS}

Special literature has different views of scientists, the experts from the business sphere and even politicians. Guo Keng Sy, one of the most famous politicians of Singapore, spoke very briefly and with some humor on this concept. "Modernization is like an elephant; it is difficult to define it, but it is easy to recognize it when you see such an animal" (Krasil'shchikov,2009).

Despite the humor of this approach, it allows us to approach the definition of modernization quite accurately. Indeed, modernization is a multifaceted process, and it can not be reduced only to some technical changes of the national economy and to the improvement of production technologies.

By the concept "modernization" in general, we can designate a complex process of changes, improvements, etc. corresponding to modern requirements in any field. This means that modernization can and should be carried out in political, economic, social, infrastructural and other fields (Krasin,2014;. Misakov, Boot, Adzhieva, 2017). And this is natural, because comprehensive modernization should cover not only economy, but also society, and political system. Entrepreneurial structures, on the contrary, believe that it is enough to confine themselves to the project modernization, although they also talk about the importance of the political will of the country leadership, professional management and the use of modern cost control methods in respect of of financial, material and other means.

We believe that the notion of "modernization" can not be considered without the concept of "innovation". In our opinion, when you define the concept of "innovation" it is necessary to adhere to the object approach, which expresses the new final result of scientific and intellectualcreative activity.

Among numerous interpretations of the term "innovation", the definition by Yu.V. Yakovets is considered by us as unusual: "innovation is the way to the unknown, this is the violation of the existing way of life and actions, this is a big risk, an adventure with a previously unknown result" (Yakovets,2004).

There is also the approach in which the propose to consider modernization as a kind of innovation (Lazarchuk ,2011). It's hard not to agree with O. Uskova [9], who suggests not to 
oppose one process to another, and do not confuse them ... Indeed, what is an object of modernization today, can become an essential infrastructure for innovation process tomorrow. Moreover, modernization is meaningless without innovation.

All mentioned above allows us to assert that modernization should be regarded as the process where innovation is an essential concept.

As for the declared topic, the policy of import substitution is tightly linked to the policy of food security provision, as the sustainable production of agricultural products and food, the increase of villager life level and quality, and the preservation of natural resources for agro-industrial production are the basis for food security. It's no secret that about $20 \%$ of food imported to Russia came under the sanctions of Western countries and the United States. At the same time, it is also not a secret that the anti-sanctions themselves are contradictory, because, on the one hand, they show that the main factor of the current undesirable situation with food supply for Russian population is the imperfection of the state agrarian policy, which in its turn requires the activation of the search for new effective strategic approaches to solve the problems of food independence. On the other hand, the existing economic risks in the agrarian sector have exacerbated multiply, which already complicates the problems of population sustainable provision with Russian agricultural products. Indeed, it should be noted that there is an increased risk of state support reduction for the AIC and the implementation of new largescale investment projects; the agricultural producers have reduced their own financial resources, which makes it impossible to invest in conditions of high credit activity and the fall of investment activity, as well as within the uncertainty of foreign sanction duration term. It should also be noted that the final results of many sub-sectors of the agroindustrial complex directly depend on seed imports $(90 \%)$, genetic material (85\%), new technologies $(75 \%)$ and agricultural machinery and equipment $(60 \%)$ (Bashieva, Kumykova, Misakov ,2015; Misakov ,2011). We must also take into account the fact that it is almost impossible to establish their production in Russian Federation, especially in the coming years. Thus, this should be regarded as a hidden threat to Russian Federation food security, which is much more dangerous than the presence of extra food products imported on the domestic market. Of course, this also needs the addition of import substitution high dependence on investment activities, in which the country is also limited significantly for today.

There is a significant distortion in the structure of farming in the depressed agrarian-oriented republics of the North Caucasus, which causes the backwardness in livestock farming with a one-sided development of the grain economy and grain export increase. All this led to the break of the technological links between crop and livestock farming, and also worsened the economic and genetic position of the livestock sector (Nogmova, Misakov,2011; Petrov, Semin,2014). It should also be noted that the stagnation of structural and technological modernization of agriculture is observed on the ground, there is practically no renewal of the basic production assets of the industry and the reproduction of the natural and economic potential (Nogmova, Misakov,2016; Cherkesov, Misakov, Betrozov,2014).

Table 1:Commodity structure of food product and agricultural raw material export and import in Russian Federation (in actual prices)

\begin{tabular}{|c|c|c|c|c|c|c|c|c|}
\hline & 2000 & 2005 & 2010 & 2012 & 2013 & 2014 & 2015 & 2016 \\
\hline & \multicolumn{7}{|c|}{ Billions of USA dollars } \\
\hline Total export & $\mathbf{1 0 3}$ & $\mathbf{2 4 1}$ & $\mathbf{3 9 7}$ & $\mathbf{5 2 5}$ & $\mathbf{5 2 6}$ & $\mathbf{4 9 7}$ & $\mathbf{3 4 4}$ & $\mathbf{2 8 5}$ \\
\hline \multicolumn{8}{|c|}{ including: } \\
\hline $\begin{array}{c}\text { agricultural raw materials } \\
\text { (except for textile) }\end{array}$ & 1,6 & 4,5 & 8,8 & 16,8 & 16,3 & 19,0 & 16,2 & 17,0 \\
\hline & \multicolumn{8}{|c|}{ In \% to total } \\
\hline Total export & $\mathbf{1 0 0}$ & $\mathbf{1 0 0}$ & $\mathbf{1 0 0}$ & $\mathbf{1 0 0}$ & $\mathbf{1 0 0}$ & $\mathbf{1 0 0}$ & $\mathbf{1 0 0}$ & $\mathbf{1 0 0}$ \\
\hline
\end{tabular}




\begin{tabular}{|c|c|c|c|c|c|c|c|c|}
\hline \multicolumn{9}{|c|}{ including: } \\
\hline $\begin{array}{c}\text { food products and } \\
\text { agricultural raw materials } \\
\text { (except for textile) }\end{array}$ & 1,6 & 1,9 & 2,2 & 3,2 & 3,1 & 3,8 & 4,7 & 6,0 \\
\hline Total import & 33,9 & $\mathbf{9 8 , 7}$ & 229 & 317 & 315 & 287 & 183 & 182 \\
\hline \multicolumn{9}{|c|}{ including: } \\
\hline $\begin{array}{l}\text { food products and } \\
\text { agricultural raw materials } \\
\text { (except for textile) }\end{array}$ & & 17,4 & 36,4 & 40,7 & 43,3 & 40,0 & 26,6 & 24,9 \\
\hline & \multicolumn{8}{|c|}{ In $\%$ to total } \\
\hline Total import & 100 & 100 & 100 & 100 & 100 & 100 & 100 & 100 \\
\hline \multicolumn{9}{|l|}{ including: } \\
\hline $\begin{array}{l}\text { food products and } \\
\text { agricultural raw materials } \\
\text { (except for textile) }\end{array}$ & 21,8 & 17,7 & 15,9 & 12,8 & 13,7 & 13,9 & 14,5 & 13,7 \\
\hline
\end{tabular}

Russia in numbers. 2017: Short collection of art./Rosstat - M., 2017 - 511 p.

As can be seen from Table 1, the commodity structure of food and agricultural product export and import in recent years is the following one. If in 2000 the export made 103 billion US dollars, then in 2014 (before the introduction of sanctions) it increased almost 5-fold and amounted to 497 billion of US dollars. In 2015, it declined by $31 \%$, and in 2016 - by $43 \%$.

It should also be noted that the record volume of food product and agricultural raw material was registered in 2013 , mainly due to wheat $(60 \%)$ and barley $(72 \%) \ldots$

Since 2014 import tend to decline throughout the nomenclature for which special measures have been set to limit supplies (fresh-frozen meat by $21 \%$, cheese and cottage cheese - by $30 \%$, etc.). At the same time, the imports from CIS countries increased by $15 \%$.

The existing success can not be estimated only as the development of agro-industrial production, because there is a significant part of political measures concerning the organization of import substitution. In our opinion, import substitution is a system of concrete measures to reduce the import-dependence, the elimination of the actual (and even possible) deficit of imported products. This approach will increase the stability and the competitiveness of national production, will generate a stable demand for domestic and food products, and also will become the form of economic innovation growth.

One of the features of agricultural production from the position of import substitution was the availability of significant stocks of unsold agricultural products, which is required to be sent to the trade network as soon as possible. In these conditions, it is required to stop the reduction of state support for lending through interest rate subsidies, and to conduct large projects in livestock production. Judging by the FSGS of RF, the decline of cattle number continues, which negatively affects the production of milk. It should be noted that about $50 \%$ of milk is produced in LPH, where it is consumed almost completely. Naturally, in the conditions of acute milk deficiency it is extremely difficult to increase the volumes of high-quality and affordable processed milk, as well as the production of butter, cheeses and fermented milk products...

Despite repeated optimistic promises by the Minister of RF Agriculture Tkachev A., it will not be possible to replace food imports with domestic products quickly, because it will take at least 10 years within tough and constantly increasing sanctions. Indeed, it is necessary to replace extremely large volumes - for example, the import of food for meat was more than $25 \%$, including beef - over $35 \%$, pork - about $30 \%$, dairy products - about $26 \%$, vegetables - about $16 \%$ etc. It should be taken into account that in the current period most of the seeds, breeding birds and 
livestock, as well as mixed fodders, premixes, agricultural machinery and processing technologies are still imported from abroad. So, for example, the imports of mixed fodders, premixes, vitamin preparations and various enzymes for agricultural animals exceed 200 million dollars a year. It should be noted that if the poultry meat is replaced almost completely, then other types of products require serious capital investments and state support, otherwise it will be impossible to achieve real food independence even in the "greenhouse" conditions of competition absence from the importing countries. All this suggests that a significant period is required to achieve food independence.

On the other hand, it should be noted that the agrarians of Russia achieved special successes in the cultivation of wheat, potatoes, vegetable oil and sugar. We believe that one of the factors of such a success is the development of Russian innovations and Russian science. It is no coincidence that at the beginning of April 2018, Russian President Vladimir Putin signed the order to increase the allocated capital investments for research and development by 1.5 times. Unambiguously, this year there will be incomparably more opportunities for the development of a workable implementation infrastructure to introduce their own scientific and technical achievements.

There are many agrarians who believe that sanctions are evil. We partially share this approach, for indeed, on the one hand, the existence of sanctions limits sharply the opportunities for new technologies, financial resources, etc. to enter the country. But on the other hand, sanctions mobilize agrarians, and the national economy in general for the development of a selfsufficient economic system. Of course, the country can not produce everything it needs, dealing only with the policy of autarky, moreover, the development of economic ties between different countries allows not only to get rid of import dependence, but, most importantly, to increase the pace of economic development. It should also be noted that not everything that is produced in the country can be considered an import substitution. Under import substitution, we propose to consider only those products of our own production that are competitive in quality and price as compared to imported products. Hence, the key condition for import substitution should be the increase of domestic product quality, the reduction of its production costs and prices. The balance between quality and price, as well as the balance between them from the consumer's point of view, can be reflected by the formula "satisfying quality at an affordable price". Only if this condition is maintained, Russian import-substituting products, equivalent in quality and price with imported products, allow the consumer to acquire the food products that are not inferior at least in terms of consumer qualities as compared with imports. For agricultural producers, and the whole Russian Federation in general, import substitution should help to increase sales markets, create new jobs, and use local production resources.

To improve the quality of manufactured products, a symbiosis is required, based on its own scientific and production potential use, scientific-technical and production borrowing, the establishment of foreign brand production in Russia, as well as the deep processing of domestic raw materials. Of course, all this should be built only on the principle of the agro-industrial complex innovative development. And this is explained by the importance of the AIC for RF food security, on the one hand, and an extremely low level of its socioeconomic and technological development.

Undoubtedly, all branches of the agro-industrial complex are in a dire need of modernization and large-scale additional investments. Only with this approach it will be possible to neutralize the gap between the technical and technological provision of agriculture, the output by domestic agricultural producers, yields etc. in Russian Federation as compared with the USA and EU countries.

Already today there is an effective import substitution of agroindustrial complex in the republics of the North Caucasus, which allows them to make a significant contribution to the country food security and increase the competitiveness of domestic agricultural products. There are positive changes in the formation of new jobs, there is the diversification of domestic 
production, and so on. The increase of agricultural production volume occurs with the re-profiling of production to manufacture the products with a high degree of deep processing.

At the same time, we must admit that the absence of serious investors in the depressed republics of the North Caucasus, the difficult geopolitical situation in the region, etc., on the one hand, an acute shortage of funds allocated under state support, on the other hand, do not allow for a systematic modernization of the agro-industrial complex and the achievement of a full-fledged import substitution in its industries. The social infrastructure needs to be improved like the production infrastructure, as well as the strategic management system by the agro-industrial complex. In the context of increasing competition, agricultural producers need to be able to adapt to their new strategies, to select a more effective model of competitive development.

A key guideline for import substitution is the production organization of such types of agroindustrial products that are most actively demanded by a specific region, have higher added value, and their production costs are capable to provide the highest return. The choice of an import substitution strategy requires the development of a separate type of auxiliary resources (administrative, monetary, technological, etc.) for the development of specific sectors of the agroindustrial complex in order to form competitive advantages.

The main factors and priority trends for the maximum effect from import substitution are the following ones:

1. a reference point for the use of corresponding technologically related production capacities;

2. the training of personnel with market thinking, as well as the workers with a sufficient level of professional training;

3. a large-scale use of own resources.

The very process of import substitution intensification in RF agroindustrial complex can be divided into three blocks.

The tasks of import substitution intensification in the agroindustrial complex of the first block are the diversification of foreign economic relations, the search of new channels for the promotion of agro-industrial products.

The tasks of import substitution intensification in the agrarian and industrial complex of the second block are the following: to increase the volumes of domestic production to a level that allows to meet the internal needs of society and business at least. Naturally, as we have shown above, this requires a complex comprehensive modernization of the entire agro-industrial complex. We also consider it is appropriate to note the necessity of western practice application concerning risk hedging - crop insurance in the daily activities of agricultural producers. It is not a secret that due to abnormal weather conditions, significant crop losses take place very often which, in its turn, have a very negative impact on the economic position of enterprises, up to the loss of their financial viability and especially those farms that wanted to modernize their production, and were forced to take loans to upgrade agricultural machinery fleet for the harvest of the future period.

The tasks of import substitution intensification in the agrarian and industrial complex of the third block are the export of agricultural products made by agricultural producers. This is not only an honorable, but also an advantageous operation, because the food products of the agro-industrial complex have an increased price at foreign markets, due to added value. Hence, it is extremely advantageous to export not just raw materials, but processed agricultural products.

It should be noted especially that the key role in the process of import substitution provision belongs to the institution of science and education located in the region. There is a lot of groundwork for an effective symbiosis of agrarian science and agro-industrial production... 
Special literature names the group of agroindustrial complex branches by the criterion of dependence on imports:

1. exotic products (bananas, etc.);

2. milk and meat products;

3. Poultry meat, pork, vegetables and fruits;

4. Confectionery and pasta products (Abdulragimov,2015).

The criterion for such a group is the degree of dependence on imports. In our opinion, the vector of agribusiness sector sustainable development strategy provision in the direction of import substitution should occur in three directions, conditionally divided by product types.

The first trend of import substitution sustainable development in the agribusiness sector consists of imported products entirely, the analogs of which are produced insufficiently in Russia. Naturally, its implementation requires to improve the existing agro-industrial production in order to gain the opportunity of production volume increase in respect of the corresponding products.

The second trend regarding the import of agricultural products, which are not produced in Russia, but which must be urgently mastered as soon as possible (for example, medicines).

The third trend concerning the products of agrarian and industrial complex which are not produced in Russian Federation as its import substitution is unprofitable or impossible because of objective factors. Such products can be attributed to the so-called critical imports, and in this case the main task is to reduce the consumption of this product, the research and the application of its indirect replacement methods ((Abdulragimov,2015).

The most effective instruments of import substitution increase in the agro-industrial complex of Russian Federation are the following ones:

1. The increase of professional training and retraining level of the agro-industrial complex staff. As you know, the basis of any enterprise activity is human capital, everything else is derivative. In order to increase the competitive advantages of the import-substituting products of the agro-industrial complex, the training and the retraining of managers and experts is particularly significant in terms of increasing competition. Among them, we can mention the scientific organization of personnel retraining with market thinking, teaching them new professional skills (foreign language, the drawing up of foreign contracts, etc.).

2. The next instrument is the diversification of the territorial and commodity structures of the external economic activity of RF AIC, within the framework of which they provide the progressive development of Russian agricultural producer participation in various specialized international organizations.

3. The development of cooperation and integration to increase the profitability of agricultural producers, the support their access to the foreign market.

4. The increase of information and consulting services to provide legal, economic and scientific and technological advice to various enterprises of the agro-industrial complex.

5. Maximum use of isolated area regional advantages in order to reduce the costs of logistics, as well as to increase the effectiveness of the participation in the created international integrated structures.

All above-mentioned instruments allow to reduce the import dependence of the agroindustrial complex significantly, to increase the final results and to create competitive advantages of the domestic agrarian economy as a whole. 


\section{CONCLUSIONS}

In the course of the study, we supplemented and refined the theoretical aspects of AIC modernization and innovative development in the context of import substitution policy implementation, substantiated the need for the correlation between modernization and innovation processes in agro-industrial complex development.

We justified that import substitution should be considered as one of the forms of economic innovation growth. The need to replace imported products raises the urgent need for agricultural development at a more dynamic pace, which is possible only through a large-scale introduction of innovative developments.

In the course of the analysis, we found that almost all the republics of the North Caucasus use obsolete and largely inefficient technologies for agricultural production, and use unprofitable and labor-intensive organizational and managerial methods and forms.

They revealed the peculiarities of the conditions for the development of modernization and innovation processes in the agroindustrial complex of agrarian-oriented republics of the North Caucasus.

We believe that it is necessary to establish the cooperation between various agro-industrial enterprises, innovators and local authorities of the republics in order to implement the mechanisms of innovative activity.

We have established that the depressed republics of the North Caucasus have all the conditions for the development of ecologically clean agriculture, the formation of agro-clusters, agrotechnoparks, vertically and horizontally integrated structures.

\section{REFERENCES}

[1] Abdulragimov I.A. (2015). Instruments for the intensification of import substitution in the agroindustrial complex of Russian Federation // Issues of Economics and Law, № 3. pp. 54 57

[2] Bashieva D.Kh., Kumykova Zh.S., Misakov A.V. (2015). Some approaches to the application of the cluster within the development and the implementation of regional economic policy. Bulletin of the Kabardino-Balkarian Science Center of the Russian Academy of Sciences, No. 1 (63). pp. 117-122.

[3] Gubanov A.G. (2017). The issues of economic development of regional agribusiness // Terra economicus, Volume 10. №1, part 3. pp. 188-191

[4] Innovative modernization of Russia / Edited by Yu.A. Krasin. - Moscow: Institute of Sociology RAS, 2014. - p. 253

[5] Krasil'shchikov V.A. (2009). Modernization: Foreign experience and lessons for Russia / Modernization of Russia: conditions, prerequisites, chances. Collection of articles and materials. Issue 1 / Ed. by V.L. Inozemtsev. - Moscow, Center for Post-Industrial Society Studies, $240 \mathrm{p}$.

[6] Lazarchuk E.V. (2011). Institutional modernization as the determining factor of innovative development // Bulletin of Siberian science, № 1 (1). pp. 421-424.

[7] Misakov A.V. (2011). Competitive-innovative approach to study the activity of agrarian and industrial complex enterprises. Economic sciences,№ 85. pp. 172-176.

[8] Misakov V.S., Boot V.V., Adzhieva A.Yu. (2017). Innovative infrastructure as the resource to achieve a balanced development of the region. Economics and Entrepreneurship, No. 6 (83). pp. 200-203.

[9] Modernization and innovation are Siamese twins // Electronic resource 
https://vz.ru/economy/2010/3/23/386229.html

[10] Nogmova L.A., Misakov V.S. (2016).The development of economic potential in the context of balanced regional development. Bulletin of the Kabardino-Balkarian Science Center of the Russian Academy of Sciences, No. 3 (71). pp. 143-148.

[11] Petrov E.A., Semin A.N. (2014).The development and mastering of innovations in Russian dairy cattle breeding // Scientific and methodical electronic journal,V.20. pp. 671-675.

[12] Cherkesov S.Kh., Misakov V.S., Betrozov M.H. (2014).Counteraction to organized crime as the basis of the regional system of economic security. Bulletin of the KabardinoBalkarian Science Center of the Russian Academy of Sciences, No. 4 (60).

[13] Yakovets Yu.V. (2004). Epochal innovations of the XXIst century / M.: Economics, 439 p.

\section{Article history:}

- Received 30 July 2018

- Accepted 1 December 2018 